\title{
Allelopathic Effect of Spinacia Oleracea L. And Psidium Guajava L. On Vigna Radiata L. Var. KM-2 and Vamban-2
}

\author{
S. Anitha* and P. Karthiga Gandhi \\ Department of Botany, Government Arts College (Autonomous), Salem - 636 007, Tamil Nadu, India.
}

\begin{abstract}
Allelopathy is the type of interaction where two organisms interact with each other in positive or in negative manner and it is mediated by secondary metabolites. In the present study, the interaction of spinach (Spinacia oleracea L.) and guava (Psidium guajava L.) with the important pulse crop green gram (Vigna radiata $L$.) was studied using leaf extracts. Two common varieties of green gram viz., KM-2 and Vamban-2 were used to study the interactions at sub-species level. Among the two tested plants, spinach was most inhibitory on seed germination and seedling growth than guava. At the species level, variation existed, the variety Vamban-2 was more susceptible than KM-2 to both plant extracts.
\end{abstract}

Key words: Leaf extract, green gram, seed germination, phytotoxicity

\section{Introduction}

Allelopathy is the chemical induction or inhibition of one species by another. The degradation of allelopathic crop may produce a variety of phytotoxins in the soil causing adverse effect in other plants (Nelson, 1996; Rice, 1984). Allelopathy refers to the beneficial or harmful effects of one plant on another plant by the release of chemicals from plant parts by leaching, root exudation, volatilization, residue decomposition and other processes in both natural and agricultural systems (Kavitha et al., 2012). Aqueous extracts of Asarum europaeum L. inhibited the germination and growth of tomato (Monica et al., 2011). Maryam et al. (2011) noticed that Papaver pavonium showed an antagonistic effect on the germination and growth of maize and brassica crops. At lower concentration, the leaf extracts of Tectona grandis, Albizia procera and Acacia nilotica had stimulatory effects on germination, growth, chlorophyll, protein, carbohydrates and proline contents of soyabean, but at higher concentrations there was a decreasing trend in the same parameters in soybean (Tripathi et al., 1998). Dave and Jain (2009) reported that extracts from fresh Penicum colonum L. plant root, stem, leaf and inflorescence showed promoting effects on seed germination in Vigna radiata L., but at higher concentration, all aqueous extracts significantly reduced root and shoot lengths compared with control. Siriporn et al. (1999) applied crude extracts from mungbean to lettuce, rice, barnyard grass and horse purslane seeds and found that the root length of those plants were inhibited when compared with control. Spinach (Spinacia oleracea L.) (Chenopodiaceae) is very rich in flavonoids (Gaikwad et al., 2010) and it is the favourite food among Indians in winter season (Guha and Das, 2008). Guava (Psidium guajava L.) (Myrtaceae) is a single source of many beneficial components of herbal remedies, which are edible without any known detrimental effect (Gutierrez et al., 2008). This plant is early considered invasive and used for reforestation programme for its easy spread of seeds and regrowth ability (Berens et al., 2008). Vigna radiata L. (green gram) ranks high among the pulse crops of India. Mature seeds are rich in protein and cooked seeds and dhal from a valuable constituent of the diet of a considerable number of people in this country (Samba Murty and Subramanyam, 1989). The varieties KM-2 and Vamban-2 are very common varieties cultivated throughout Tamil Nadu in all seasons. Cultivation of spinach and green gram in same field is done during different seasons. Hence, the present study is undertaken with an objective to check the effect of two different kinds of plants; competitor (spinach) and invasive (guava) on important food crop green gram.

\section{Materials and methods}

Seeds of Vigna radiata L. Var. KM-2 and Vamban-2 were collected from Agricultural Office, Omalur, Salem and work was carried out in the Department of Botany, Government Arts College, Salem-7. Leaves of guava (Psidium guajava L.) and spinach (Spinacia oleracea $\mathrm{L}$.) were collected and shade dried for a period of 15 days. Middle leaves were collected from the twigs ( $3^{\text {rd }}$ and $4^{\text {th }}$ leaves). 10 gram leaf powder is extracted with $250 \mathrm{ml}$ distilled water. Various dilutions were made such as $25 \%, 50 \%, 75 \%$ and $100 \%$ using distilled water by keeping the extract as $100 \%$ solution. Distilled water was used as control. For each treatment 15 numbers of uniform healthy seeds were used. The seeds were disinfected with $0.1 \%$ Mercuric Chloride solution (W/V) for four minutes and then soaked in control and different concentrations of leaf extract $(25 \%, 50 \%, 75 \%, 100 \%)$ for $24 \mathrm{hrs}$ prior for germination. The treated seeds were kept on the surface of wet cotton soaked with distilled water 
and plant extracts which were used to treat the seeds in petriplates. This wet cotton bed with seeds were kept under dark condition for 2 days and then transferred to the normal room condition. Addition of water and respective plant extracts was done when the cotton became dry. An observation for seed germination was recorded after $2^{\text {nd }}$ and $5^{\text {th }}$ day of sowing. After $2^{\text {nd }}$ day of the treatment, the emergence of radicle is recorded and after $5^{\text {th }}$ day complete germination of the seeds was considered. To analyze the effect of leaf extract on seedling growth, the length of seedlings were measured at $7^{\text {th }}$ day and it is recorded. Triplicates were maintained for each experiment and all the experiments repeated thrice.

Abdul Baki and Anderson (1973) method was used to analyze the phytotoxicity of plant extracts,

Phytotoxicity percentage $=(($ Length of control seedling - Length of treated seedling $) \div$ Length of control seedling) $\times 100$

\section{Results and discussion}

In the present study, leaf extracts of guava (Psidium guajava L.) and spinach (Spinacia oleracea L.) were tested for their allelopathy activity against Vigna radiata L. varieties KM-2 and Vamban-2. The allelopathy effect was tested both at seed germination and seedling growth stage. Among the two plants tested, spinach showed more inhibition of seed germination and seedling growth than guava in both varieties. The tested varieties KM-2 and Vamban-2, both showed similar rate of inhibition in seed germination at $100 \%$ extract and $75 \%$ spinach extract. In other lower concentrations, KM-2 was less affected than Vamban-2 (Table 1 and 2). There was a variation observed in seed germination rate with guava extract in both the varieties, the seed germination rate decreased with increase in extract concentration. But compared with spinach, the inhibition rate was less at specific concentrations (Table 1 and 2). Similar to our results, inhibition of seed germination observed in charlock with Glaucium species (Ghorbanli et al., 2011), in soybean and chive with ginger (Chun-Mei et al., 2008), in sesame, corn, sorghum and sunflower with mungbean (Lertmongkol et al., 2011). The speed of seed germination was also decreased at high concentrations of plant extract. This is evident from the results that seed germination in control was $100 \%$ on $2^{\text {nd }}$ day itself but in treatments, seed germination delayed significantly with increase in plant extract concentration. Only on $5^{\text {th }}$ day the utmost germination observed (Table 1 and 2). This result correlates with the results of Khaliq et al. (2011), where delayed seed germination observed in rice treated with crop residues of sorghum, sunflower and brassica. In the present study, phytotoxicity of both plants is presented in Figure 1 and 2. Similar to seed germination, seedling growth was extensively affected by spinach than guava. The variety KM-2 was more inhibited than Vamban-2 (Figure 1 and 2). Consistent with our results, the length of shoot and root were reduced in green gram and black gram by V.negundo (Kavitha et al., 2012), shoot and root length in charlock by Glaucium species (Ghorbanli et al., 2011), seedling growth in Amaranthus retroflexus by sorghum (Yarnia et al., 2009), and radicle growth in wheat by Prosopsis Juliflora (Siddiqui et al., 2009).

\section{References}

[1]. Abdul-baki BAA. and Anderson JD (1973). Relationship between decarboxylation of glutamic acid and vigour in soybean seed. Crop Science, 13: 222-226.

[2]. Berens, D.G., Farwig, N., Schaab, G. and Böhning-Gaese, K. (2008). Exotic guavas are foci of forest regeneration in Kenyan farmland. Biotropica, 40: 104-112.

[3]. Chun-Mei Han, Kai-Wen Pan, Ning Wu, Jin-Chuang Wang and Wei Li (2008). Allelopathic effect of ginger on seed germination and seedling growth of soybean and chive. Scientia Horticulturae, 116 (3): 330-336.

[4]. Dave, D.N. and Jain, B.K, (2009). Allelopathic effects of Chenopodim album L. on in vitro seed germination of the Triticum aestivium L., The Journal of Indian Botanical Society, 88: 191-194.

[5]. Gaikwad PS, Shete RV and Otari KV. (2010). Spinacia oleracea L. A Pharmacognostic and Pharmacological overview. International Journal of Research in Ayurveda and Pharmacy, 1(1), 78-84.

[6]. Ghorbanli, M., Gran A. and Zolfaghary A. (2011). The study of Allelopathic potential in three species of Glaucium Mill. on Sinapis arvensis L.Iranian Journal of Plant Physiology 2 (1): 321-324.

[7]. Guha, D and Das, S. (2008). CNS depressive role of aqueous extract of Spinacia oleracea L. leaves in adult male mice albino rats. Indian J Exp Biol., 46: 185-190.

[8]. Gutierrez, R.M., Mitchell, S and Solis, R.V. (2008). Psidium guajava L. A review of its traditional uses, Phytochemistry and Pharmacology. J. Ethnopharmacol., 117, 1-27.

[9]. Kavitha, D. Prabhakaran, J and Arumugam, K, (2012): Allelopathic influence of Vitex negundo L. on germination and growth of Green gram (Vigna radiata (L.) R. Wilczek) and Black gram (Vigna mungo (L.) Hepper). International Journal of Ayurvedic and Herbal Medicine 2(1): 163-170.

[10]. Khaliq A, Matloob A, Cheema ZA and Farooq M (2011). Allelopathic activity of crop residue incorporation alone or mixed against rice and its associated grass weed jungle rice (Echinochloa colona [L.] link). Chilean Journal of Agricultural Research 71(3): 418423 .

[11]. Letmongkol., Sarobol, E.D and Cha-um Premasthira (2011). Allelopathic effects of mung bean (Vigna radiata L.) on subsequent crops. Kasetsart J. (Nat.Sci.) 45:773-779.

[12]. Maryam Ehsan, Muhammad Ibrar, Niaz Ali and Sarah Mubarak, S, (2011). Laboratory experiment to test Papaver pavoninum Fisch. and C.A. Mey. allelopathic effect against test species maize and brassica. J. Bio. \& Env. Sci. 1(5); 49-56.

[13]. Monica. M., Anca. P., Lucia. M., Zorica, V and Georgeta, M, (2011). Allelopathic potential of Asarum europaeum toward Lycopersicon esculentum. Analele universitatii din Oradea- Fascicula biologie Tom, XVIII: 1.39-44.

[14]. Nelson, C.J. (1996). Allelopathy in cropping systems. Agronomy Journal, 88:991-996.

[15]. Rice, E. L, (1984). Allelopathy, Academic Press, New York, pp441. 
[16]. Samba Murty, A.V.S.S and Subrahmanyam, N.S, (1989). Text book of Economic Botany. 142,144,147.

[17]. Siddiqui S, Bhardwaj S, Khan SS and Meghvanshi MK (2009). Allelopathic Effect of Different Concentration of Water Extract of Prosopsis Juliflora Leaf on Seed Germination and Radicle Length of Wheat (Triticum aestivum Var-Lok-1), American-Eurasian Journal of Scientific Research, 4 (2): 81-84.

[18]. Siriporn, Z.P., Seenaunsalung and Premasthira, C, (1999). Mungbean (Vigna radiata L. Wilczek) as a potential crop for weed control in Proceedings of the $4^{\text {th }}$ National plant protection. Crop Protection technology in the next Decode. Bangkok, Thailand, pp. $175-180$.

[19]. Tripathi, S., Tripathi, A., Kori, D.C and Tiwari, S, (1998). Effect of tree leaves aqueous extracts on germination and seedlings growth of soyabean. Allelopathy J. 5(1): 75-82.

[20]. Yarnia M, Khorshidi Benam MB and Farajzadeh Memari Tabrizi E (2009). Allelopathic effects of sorghum extracts on Amaranthus retroflexus seed germination and growth. Journal of Food, Agriculture \& Environment, 7: 770-774.

Table1: Effects of spinach (Spinacia oleracea L.) and guava (Psidium guajava L.) leaf extracts on seed germination in Vigna radiata L. var. KM-2

\begin{tabular}{|l|c|c|c|c|c|c|c|c|c|c|}
\hline \multirow{2}{*}{ Plant species } & \multicolumn{8}{|c|}{ Percentage of seed germination } \\
\cline { 2 - 11 } & \multicolumn{6}{|c|}{$\mathbf{2}^{\text {nd }}$ day } & \multicolumn{5}{|c|}{$5^{\text {th }}$ day } \\
\cline { 2 - 11 } & $\mathrm{C}$ & $25 \%$ & $50 \%$ & $75 \%$ & $100 \%$ & $\mathrm{C}$ & $25 \%$ & $50 \%$ & $75 \%$ & $100 \%$ \\
\hline S. oleracea L. & 100 & 73.3 & 60 & 13.3 & 6.6 & 100 & 80 & 60 & 20 & 6.6 \\
\hline P. guajava L. & 100 & 86.6 & 60 & 33.3 & 20 & 100 & 93.3 & 80 & 46.6 & 26.6 \\
\hline
\end{tabular}

Table2: Effects of spinach (Spinacia oleracea L.) and guava (Psidium guajava L.) leaf extracts on seed germination in Vigna radiata L. var. Vamban-2

\begin{tabular}{|c|c|c|c|c|c|c|c|c|c|c|}
\hline \multirow{3}{*}{ Plant species } & \multicolumn{10}{|c|}{ Percentage of seed germination } \\
\hline & \multicolumn{5}{|c|}{$2^{\text {nd }}$ day } & \multicolumn{5}{|c|}{$5^{\text {th }}$ day } \\
\hline & $\mathrm{C}$ & $25 \%$ & $50 \%$ & $75 \%$ & $100 \%$ & $\mathrm{C}$ & $25 \%$ & $50 \%$ & $75 \%$ & $100 \%$ \\
\hline S. oleracea L. & 100 & 66.6 & 33.3 & 13.3 & - & 100 & 60 & 40 & 20 & 6.6 \\
\hline P. guajava $\mathrm{L}$. & 100 & 66.6 & 60 & 40 & 6.6 & 100 & 86.6 & 80 & 40 & 13.3 \\
\hline
\end{tabular}

Figure1: Effect of spinach (Spinacia oleracea L.) and guava (Psidium guajava L.) leaf extracts on seedling growth in Vigna radiata L. var. KM-2

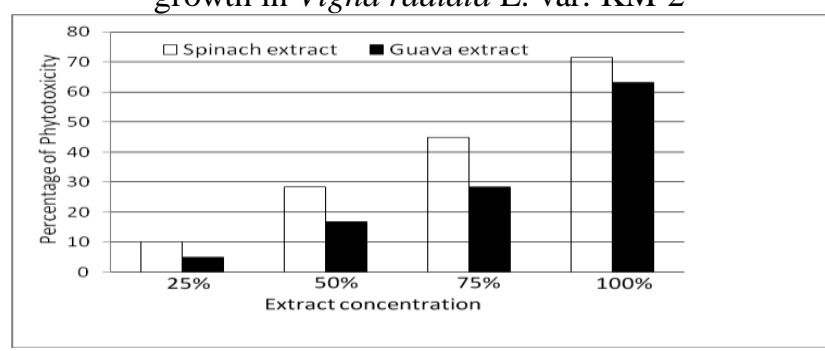

Figure2: Effect of spinach (Spinacia oleracea L.) and guava (Psidium guajava L.) leaf extracts on seedling growth in Vigna radiata L. var. Vamban-2

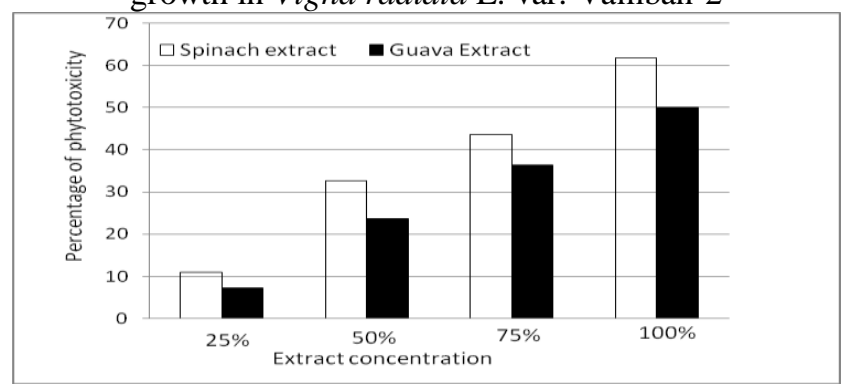

